Pamiętnik Literacki 2021, 3, s. 5-29
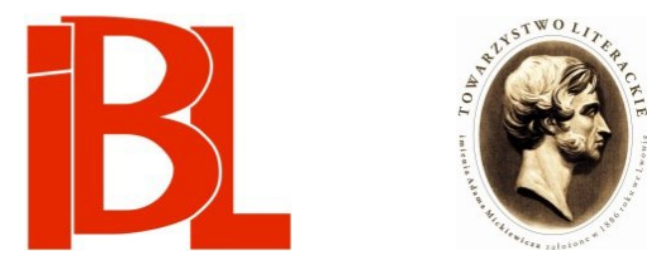

\title{
Norwid postsekularny? Tezy i próby
}

Michał Kuziak 


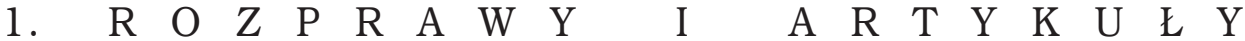

Pamiętnik Literacki CXII, 2021, z. 3, PL ISSN 0031-0514

DOI: $10.18318 / \mathrm{pl} .2021 .3 .1$

MICHAŁ KUZIAK Uniwersytet Warszawski

NORWID POSTSEKULARNY? TEZY I PRÓBY

\section{W Roku myśliwego Czesława Miłosza czytamy:}

Gdyby tak ktoś napisał studium porównawcze o trzech pisarzach urodzonych prawie równocześnie: Melville, Dostojewski, Norwid. Pomimo wszelkich różnic, także różnic tła, skoro już przewrót kapitalistyczny w Ameryce Melville'a i zaledwie początki kapitalizmu w Rosji Dostojewskiego, obaj są profetyczni, bo szamoczą się z kryzysem wiary chrześcijańskiej - pierwszy zrozpaczony, że nie może uwierzyć, drugi chcący uwierzyć za wszelką cenę i zmagający się ze swoim diabłem. Norwid zacny, ani krzty demonizmu, ale powstaje pytanie, czy literatura bez tej domieszki nie jest dla nas już kuchnią zanadto jarską ${ }^{1}$.

Pytanie to pozostawiam na boku. Jest zasadne, lecz za bardzo wkracza w sferę gustu, a po części sytuuje się też poza sferą interesujących mnie tu zjawisk. Zajmuje mnie bowiem sama religijność autora Vade-mecum. Wiemy o niej sporo. Cyprian Norwid zwykle bywa traktowany jako najbardziej obok Zygmunta Krasińskiego ortodoksyjny katolik polskiego romantyzmu - jak powiada Miłosz: „zacny”. Ortodoksyjność widać choćby w cechującym poetę sposobie czytania Pisma Świętego, hermeneutycznym, acz powściąającym typowy dla romantyków podmiotowy wkład interpretacyjny ${ }^{2}$. Według Aliny Merdas:

twórczość [Norwida] ukazuje twarz człowieka głęboko wierzącego i prezentuje, mówiąc językiem poety, „Zupełne” chrześcijaństwo. Jest ortodoksyjna, zgodna z doktryną Kościoła katolickiego. Nie znajdziemy w niej „religii ojczyzny”, charakteryzującej Wielką Emigrację, ani też religijności romantycznej, wyrażającej się w licznych kierunkach iluminizmu czy teozofii, poddanej „romantycznemu czuciu” i obojętnej na zawartość dogmatyczną wiary ${ }^{3}$.

Oczywiście trzeba pamiętać o koncepcjach formułowanych przez poetę w okresie tuż po Wiośnie Ludów, kiedy to - jak zauważyła Zofia Trojanowiczowa - splata-

$1 \quad$ Cz. Miłos z, Rok myśliwego. Kraków 1991, s. 39.

2 Kontekst ten pokazała A. M e r d a s (Łuk przymierza. „Biblia” w poezji Norwida. Lublin 1983). Zob. też Z. Stefa now ska, Norwidowski romantyzm. W: Strona romantyków. Studia o Norwidzie. Lublin 1993, s. 70. Funkcjonowanie idei i struktur biblijnych w poezji romantyków, splatających „sakralne” z „sekularnym” czy „pogańskim”, opisał M. H. Abrams (Natural Supernaturalism: Tradition and Revolution in Romantic Literature. New York 1971). U Norwida także pojawia się np. schemat upadku i reintegracji, ale jest on ujęty ortodoksyjnie, nie staje się podstawą wizjonerskiego, profetycznego opracowania.

3 A. M e rd a s, Ocalony wieniec. Chrześcijaństwo Norwida na tle odrodzenia religijnego $w$ porewolucyjnej Francji. Warszawa 1995, s. 7. 
jąc wizję chrześcijaństwa $\mathrm{z}$ millenaryzmem, zbliżył się on do mesjanizmu romantycznego ${ }^{4}$. Znamy wpływ Biblii na myśl i poezje Norwida, na jego praktykowanie religijności - Biblia towarzyszy mu na co dzień, pozwala roztrząsać rozgrywające się wydarzenia ${ }^{5}$. Norwid dysponował wiedzą $z$ zakresu historycznej krytyki Pisma Świętego, pragnął zająć się tą dziedziną ${ }^{6}$. Przede wszystkim należy jednak uwzględnić wymiar religijny, chrześcijański twórczości poety, przejawiający się w wielu aspektach jego dzieł ${ }^{7}$. Badacze rozważali ponadto możliwy i realny wpływ Norwida na religijność przyszłych pokoleń, w tym na Karola Wojtyłę. Autor Vade-mecum miałby wyznaczać szlaki katolickich modernistów i refleksji Soboru Watykańskiego II, miałby także oddziaływać na personalistów katolickich ${ }^{8}$. Stefan Sawicki, podejmując kwestię wartości chrześcijańskich w poezji Norwida, wskazywał, że mamy tu do czynienia $z$ „obecnością religii [...] autentyczną i pierwszoplanowa” nie tylko w aspekcie tematycznym, ale i w związku $\mathrm{z}$ religijnym widzeniem świata ${ }^{9}$. Podobnie Józef Tischner pisał o religijnym myśleniu poety, „wielkim”, „tragicznym”, programowo niesystemowym, o myśleniu, w którego centrum mieści się „rozumienie dramatu dziejowego, przede wszystkim dramatu własnego narodu poprzez treści niesione przez Ewangelię i rozumienie Ewangelii poprzez dramat własnego narodu. Rozumienie to nie ma zaspokajać czyjejś ciekawości spekulatywnej, lecz winno służyć wyzwoleniu człowieka i narodu" ${ }^{10}$. Naturalnie Tischner zdawał sobie sprawę $z$ uniwersalizującej, ponadnarodowej tendencji myśli poety. Co istotne dla podjętych tu rozważań, Marian Piechal konstatował: „Norwid był chyba ostatnim już poetą, który jeszcze bez zastrzeżeń wierzył"11.

Niewątpliwie tytuł tego artykułu należałoby zakończyć większą liczbą pytajników. Czy można jednak przyjąć bez wahania, że religijność Norwida ma charakter posłuże się językiem romantyków i przywołam określenie Friedricha Schillera „naiwny”? Że stanowi zjawisko, które kształtuje się nawet nie tyle wbrew oświece-

4 Z. Trojanowiczowa, Cypriana Norwida mesjanizm sztuki, czyli o poszukiwaniu „wszech-doskonałości”. W: Romantyzm. Od poetyki do polityki. Interpretacje i materiały. Wybór, red. A. A r twińs ka, J. B or ow czyk, P. Śniedziewski. Kraków 2010.

5 W XIX wieku indywidualne czytanie Pisma Świętego nie było częste, co wynikało z kościelnego zakazu i z dominacji tradycji w nauczaniu Kościoła katolickiego; w czasach Norwida ów zakaz został zniesiony, ale poeta najpewniej o tym nie wiedział. Warto dodać, że korzystał on z Biblii gdańskiej, z Biblii J. Wujka oraz z Wulgaty, również we francuskim przekładzie. Zob. Merdas, Łuk przymierza, s. 31.

6 Zob. ibidem, s. 36.

7 Zob. np. I. Sławińs ka, „Chrześcijańska drama” Norwida. „Studia Norwidiana” t. 3/4 (19851986). - T. Skubala nka, Z problematyki stylistycznej wierszy Norwida. Język religii - język poezji. W zb.: Norwid a chrześcijaństwo. Red. J. Fert, P. C hle bow ski. Lublin 2002. - A. D un a j s ki: Symbolika religijna $w$ pismach Norwida. W zb.: Symbol $w$ dziele Cypriana Norwida. Red. W. Rz o ń c a. Warszawa 2011; Semantyczne funkcje obiektów sakralnych i parametrów liturgicznych w pismach Norwida. W zb.: Norwidowski świat rzeczy. Red. P. A b r i s z e w s k a [i in.]. Toruń 2018.

8 Zob. M. Masłow s ki, Etyka i metafizyka. Perspektywa transcendencji poziomej we wspótczesnej kulturze polskiej. Warszawa 2011, s. 16 n.

9 S. S a w i c ki, Chrześcijańskie wartości poezji Norwida. Lublin 1986, s. 6.

10 J. Tis c h n e r, Ptakom na wędrówce. W zb.: Cyprian Norwid. W setna rocznicę śmierci poety. Materiały z sesji poświęconej życiu i twórczości C. Norwida (27-29 października 1983). Red. S. B u rk ot. Kraków 1991, s. 50.

11 M. Pi e c ha 1, Mit Pigmaliona. Rzecz o Norwidzie. Warszawa 1974, s. 174. 
niowym i pozytywistycznym tendencjom sekularyzacyjnym, związanym zwłaszcza z rozwojem nowoczesnej nauki i ogólnie racjonalizmu, ile przy całkowitym ich pominięciu (taki bowiem wniosek da się wysnuć z lektury większości opracowań poświęconych religijności poety)? I czy jedynym sposobem na dotarcie do specyfiki owej religijności jest interpretacja uwzględniająca kontekst twórczości Norwida oraz Biblii, ewentualnie - rzadziej - współczesnej mu refleksji religijnej?

W pewnym sensie cała kwestię da się sprowadzić do pytania o to, czy poeta i intelektualista mogą istnieć poza tym, co Michel Foucault nazwał „episteme”, a więc poza tym, co wyznacza możliwość bądź niemożliwość pomyślenia czegoś w danym czasie, poza polem epistemologicznym, które funduje przejawiający się w dyskursie porządek ${ }^{12}$. Od razu podkreślę: autor Czarnych kwiatów próbował tak istnieć, m.in. występując przeciw (po)romantycznemu upodmiotowieniu ładu rzeczy, a zatem również przeciw tendencjom postsekularnym, o czym świadczą np. następujace słowa: ,jestem we walce $z$ całym kierunkiem sztuki i wiedzy” (PW-10 153) ${ }^{13}$. Czy jednak mu się to udało? A jeśli tak, to w jakim stopniu? Piszacc o owym upodmiotowieniu w sztuce, Charles Taylor - ważny reprezentant dzisiejszej myśli postsekularnej, do którego zaraz powrócę - podkreśla, że ma na myśli sposób docierania do zjawisk, a nie same zjawiska. Jako przykład podaje motyw aniołów w twórczości Rainera Marii Rilkego:

współczesne „anioły” - w odróżnieniu od swoich protoplastów - muszą być od nas zależne albo też: zakotwiczone w języku. Nie da się ich oddzielić od pewnego języka artykulacji, który jest niejako ich żywiołem. Ten język $\mathrm{z}$ kolei jest zakorzeniony w indywidualnej wrażliwości poety i zrozumiały jedynie dla tych, których wrażliwość współbrzmi z tamtą ${ }^{14}$.

Norwid pragnął, by anioły pozostały fragmentem obiektywnego - jednego i jedynego - ładu rzeczy, ładu, który nas przerasta, stanowi wezwanie oraz wyzwanie i jest dostępny dla każdego w taki sam sposób, niezależnie od języka i indywidualnej wrażliwości, choć według poety ta wrażliwość też odgrywa ważną rolę w doświadczeniu religijnym.

Najpierw trzeba wyjaśnić pewne (możliwe) nieporozumienie. Otóż czym są sekularyzacja i - w efekcie - postsekularyzm? A raczej - jak będę rozumiał te zjawiska? We wstępnej części sporządzonego przez Norwida [Memoriału w sprawie „Towarzystwa Uszanowania Człowieka”], postulującego założenie tytułowego towarzystwa, które miałoby na celu „wprowadzenie człowieczej pokory we warunki socjalne i historyczne - normalnie, mocno, raźnie, bez-wiolentnie, niezłomnie”, czytamy: „Dwie Ewangelie $z$ niesłychaną szybkością swiat cały obiegły: s p iry c i i system D a r w i n a - żadna gromniej i szybciej nie szła w obieg nigdy" (PW-6 643). Rozpoznanie to w zasadzie bez żadnych wątpliwości można zakwalifikować jako post-

W związku z zajmującą mnie tu kwestią należałoby uruchomić kontekst XIX-wiecznych rozterek religijnych towarzyszących twórcom i myślicielom epoki. $Z$ powodu braku miejsca na to wspomnę tylko o encyklikach papieskich, choćby o Quanta cura Piusa IX z 1864 roku, potępiającej błędy modernizmu i łączone $\mathrm{z}$ nim procesy sekularyzacyjne.

13 W ten sposób odsyłam do wydania: C. N o rwi d, Pisma wszystkie. Zebrał, tekst ustalił, wstępem i uwagami krytycznymi opatrzył J. W. Go mulicki. T. 1-11. Warszawa 1971-1976. Liczba po dywizie oznacza tom, a po spacji - stronicę.

14 Ch. Taylor, Etyka autentyczności. Przeł. A. Pawele c. Kraków 1996, s. 70. 
sekularne, odsłania ono przy tym specyfikę pejzażu myślowego drugiej połowy XIX wieku ${ }^{15}$.

Jak podkreśla jeden ze współtwórców myśli postsekularnej, cytowany już Taylor, kłopoty ze zdefiniowaniem zjawiska zaczynaja się przy próbie opisania tego, czym jest sekularyzacja. Badaczowi chodzi o jej wersję wywodzącą się z oświecenia, a związaną z linearnie i jednokierunkowo pojmowaną kategoria postępu, mającego realizować się w nowoczesności m.in. przez odczarowywanie świata, pozbawianie go religijnej iluzji - tak patrzył na rozwój dziejów i myśli np. Auguste Comte w Cours de philosophie positive. Doświadczenie $\mathrm{XX}$-wieczne pozwoliło poddać to ujęcie krytyce i dostrzec, że tendencje sekularyzacyjne nie obejmują całej kultury ani nawet w niej nie dominuja. I to współistnienie tendencji sekularyzacyjnych $z$ tendencjami religijnymi Taylor określa mianem postsekularyzmu. Postsekularyzm wiąże się zatem z możliwością wyboru - z sytuacją, w której wiara, religia nie sa jedyną dostępną opcją światopoglądową i w której utracony został uniwersalny horyzont pojęciowy podtrzymujacy ów stan. Doświadczenie takie badacz ukazał w przywołanym fragmencie o aniołach w poezji Rilkego. W cytowanej wypowiedzi z [Memoriału...] Norwid pisze w sposób krytyczny właśnie o takiej sytuacji, o pojawieniu się dwóch „Ewangelii” konkurencyjnych wobec Biblii: ewolucjonizmu Charlesa Darwina oraz koncepcji spirytualistycznych. Z krytyką poety spotykają się gdzie indziej także praktyki magiczne, sekty religijne (np. towiańczycy), ponadto Norwid ostrożnie podchodzi do przeżyć mistycznych, zwłaszcza do tych XIX-wiecznych. Owe zjawiska, noszące ślady religijności czy duchowości, pozostają wszak w niezgodzie z ortodoksją katolicką, bo - jak komentuje poeta - odznaczają się m.in. przewagą indywidualizmu, pierwiastka tytanicznego, narcystycznego i partykularyzmu nad uniwersalizmem. „D a r w in słaby jest i bez dobrej wiary - zwierzęta nie są przodki nasze, ale sa paraboliczni pokrewni, o czym i Apostoł Paweł o naturze nadmienia”, dodaje Norwid, eksponując wyższość nauki biblijnej nad nowoczesnym przyrodoznawstwem (PW-6 643) ${ }^{16}$.

Dla Taylora sekularyzm i w efekcie postsekularyzm zaczynają się tam, gdzie dochodzi do rozpadu przednowoczesnej, teistycznej, poddanej transcendentnemu sensowi wizji świata, charakteryzującej się całościowością, spójnością i hierarchicznością, gdzie destrukcji ulega wizja ładu kosmicznego, wielkiego łańcucha bytu. Procesowi temu towarzyszą wzrost wpływów rozumu instrumentalnego oraz sekularyzacja poszczególnych sfer rzeczywistości społecznej i kulturowej - zwłaszcza życia publicznego (państwo uniezależnia się od Kościoła, więź wspólnotowa przestaje być więzią religijną) ${ }^{17}$; zyskuje na znaczeniu kultura umasowionego indywidualizmu i autentyczności, też realizacji własnych pragnień duchowych. Życie zostaje pozbawione dawnych autorytetów i rytuałów. Co ciekawe, Taylor zwraca

Zob. Constructing Nineteenth-Century Religion: Literary, Historical, and Religious Studies in Dialogue. Ed. J. King, W. J. Werne r. Columbus 2019. - G. Min o is, Historia ateizmu. Niewierzacy $w$ świecie zachodnim od jego początków do naszych czasów. Przeł. W. Kle n czon. Warszawa 2019, s. 527 n.

16 Błąd Norwida dotyczący św. Pawła prostuje P. Marchewka ( $Z$ romantycznych rodowodów biblijnych. Apostot Paweł $w$ twórczości Cypriana Norwida. Poznań 2009, s. 106 n.).

17 Zob. M. G a u c h e t, La Religion dans la démocratie. Parcours de la laïcité. Paris 1998, s. 83 n. 
uwagę także na to, że nowoczesność rozwija pewne aspekty chrześcijaństwa, np. prawa człowieka i obywatela, które według niego mają źródło w etyce religijnej. W rezultacie otwiera się wymiar wielości dostępnych światopoglądów, również religijnych (granica między sacrum a profanum zaciera się, decyduje o niej już nie tylko Kościół), dochodzi do pluralizacji i zeświecczenia źródeł moralnych. Badacz stwierdza, że ta nowa sytuacja - konkurencji światopoglądowej - wytwarza specyficzną przestrzeń, w której, w sposób inny niż w epoce przednowoczesnej, kształtuje się doświadczenie religijne ${ }^{18}$.

Nieco inaczej na postsekularyzm patrzy Michał Warchala, piszacy o romantycznych - niemieckich i angielskich - źródłach tego zjawiska. Sytuuje się on bliżej Habermasowskiego ujęcia problemu, eksponującego istnienie opozycji między naturalizmem a religią. Projekt oświecenia zakładał wyparcie tej opozycji, czy może lepiej - racjonalizację, odczarowanie, natomiast w XXI wieku filozof obserwuje jej powrót, przy czym traktuje ten powrót ambiwalentnie: jako cenną reakcję na panowanie rozumu instrumentalnego i zarazem jako zagrożenie dla sfery publicznej ${ }^{19}$. Według Habermasa wyobrażenia religijne do dzisiaj zawierają ważny potencjał sensu, który mógłby nas wzbogacić (a też uchronić przed odhumanizowanym naturalizmem, będącym konsekwencją sekularyzacji) pod warunkiem nadania im kształtu racjonalnego i wydobycia aspektów laickich wpisujących się w perspektywę humanistyczną. Warchala przyjmuje, że postsekularyzm ma związek z wewnętrzną logiką nowoczesności. Stanowi autokorektę jej rozwoju. Romantyzm - jak pokazuje badacz - to pierwszy moment postsekularny w dziejach kultury europejskiej, a świadczy o tym twórczość Williama Blake’a, Williama Wordswortha, Friedricha Schlegla czy Novalisa:

w ich twórczości ujawniają się dwie charakterystyczne cechy postsekularyzmu. Pierwszą z nich jest konstatacja, że religia instytucjonalna jako zwarty system została ostatecznie pogrzebana przez oświeceniową krytykę i w swojej tradycyjnej postaci może być już tylko martwą, coraz bardziej ciążącą i opresyjną skorupa. Druga cecha sprowadza się do przekonania, że religijne pojęcia i intuicje są mimo wszystko na tyle cenne i odsłaniają na tyle szeroki horyzont znaczeń, że warto je zachować, włączając w nową formę, która posłuży z kolei do walki $z$ co bardziej redukcyjnymi przejawami oświeceniowej ideologiii ${ }^{20}$.

Ch. Taylor, A Secular Age. Cambridge, Mass., 2007. Zob. też Literatura a religia. Wyzwania epoki świeckiej. T. 1: Teorie i metody. Red. T. Garbol, Ł. Tis chn e r. Kraków 2020.

Np. J. Ha b e rm a s, Między naturalizmem a religia. Rozprawy filozoficzne. Przeł. M. Pa ńk ó w. Warszawa 2012.

20 M. W a r c h a la, Religia romantyczna. Z genealogii myślenia postsekularnego. W zb.: Deus otiosus. Nowoczesność $w$ perspektywie postsekularnej. Red. A. Bielik-Robs on, M. A. Sosnow ski. Warszawa 2013, s. 169-170. W podobnym duchu swoje rozważania poświęcone francuskiej literaturze romantycznej prowadzi T. Szy mań s ki (Postsekularne oblicza francuskiego romantyzmu: Pierre Leroux, Edgar Quinet i „religia uniwersalna”. W zb.: Mit - religia - nowoczesność. Cena emancypacji. Red. T. Maj ews ki, M. Kuster. Wyd. 2, zmien. i rozszerz. Kraków 2019), zwracając uwagę na zachodzące w XIX-wiecznej Francji procesy sekularyzacyjne oraz na religijną reakcję na nie w twórczości P. Leroux oraz E. Quineta: „i jeden, i drugi, w pełni afirmując postępowe wartości rewolucyjne i republikańskie oraz konsekwencje ich historycznej eksplozji w nowoczesności emancypującej się od religii, dostrzega jednocześnie ograniczenia i wyjałowienie świata, który radykalnie zrywa $\mathrm{z}$ religią, odcinając się w ten sposób od swoich źródeł oraz swych mitów założycielskich” (ibidem, s. 55). W Polsce perspektywę postsekularną, avant la lettre, wprowadził Cz. Miło s z, pisząc w Ziemi Ulro (Warszawa 1982, s. 108 n.) o „romantycznym przesileniu kultu- 
Narzędzi postsekualarnych do lektury Norwida użyła Magdalena Siwiec, nawiązując do myśli Taylora i zestawiając poetę z Charles'em Baudelaire'em. Do kwestii tej powrócę dalej. Zatrzymajmy się na moment przy doświadczeniu religijnym romantyków, szczególnie przy jednym wątku. Myślę o rozwiniętym w romantyzmie swoistym toposie z Pierwszego Listu do Koryntian św. Pawła (13, 12): „Videmus nunc per speculum in aenigmate, tunc autem facie ad faciem [Teraz widzimy jakby w zwierciadle, niejasno; wtedy zaś 〈zobaczymy〉 twarza w twarz]". Chodzi tu o niedoskonałość ludzkiego poznania, które tyleż przybliża, co oddala prawdę; dopiero po śmierci, dzięki życiu wiecznemu, będziemy mogli obcować z prawdą bezpośrednio. U wielu romantyków pojawia się przekonanie, że czas, w którym przyszło im żyć, to moment szczególnego oddalenia od Boga. Przywołam tu Novalisa. W Henryku von Ofterdingen do bohatera wybudzonego ze snu o błękitnym kwiecie ojciec mówi:

Minęły już czasy, gdy snom towarzyszyły boskie objawienia, i nigdy nie pojmiemy, co odczuwali wybrani mężowie, o których Biblia opowiada. Wówczas sny, jak też sprawy ludzkie musiały mieć odmienną naturę. W tej epoce, w której żyjemy, zanikła już bezpośrednia łączność z niebem. Dawne historie i pisma są teraz jedynymi źródłami, dzięki którym w udziale przypada wiedza o ponadziemskim świecie - tyle, ile jest konieczne - a zamiast wyraźnych objawień Duch Święty przemawia teraz pośrednio przez rozsądek mądrych i życzliwych mężów, przez sposób życia i losy pobożnych ludzi ${ }^{21}$.

Ta diagnoza sytuacji po oświeceniu niejednokrotnie powraca u niemieckiego poety, przekonanego, że człowiek zatracił dostęp do głębokiego sensu szyfru, który przenika naturę i jest przekazem Boskim. Bohater powieści rozpoczyna wędrówkę ku odzyskaniu tego języka (jego ojciec też podją swoją wędrówkę, skończył wszakże w wymiarze doczesnym, a nie metafizycznym). U Novalisa znajdujemy konstrukt mitycznego „kiedyś”, Wielkiej Całości, w której wyższy sens był człowiekowi bezpośrednio dostępny i organizował całość jego życia - zarówno indywidualnego, jak i społecznego.

Oczywiście literatura romantyzmu europejskiego przynosi więcej fragmentów ujawniajacych związane $z$ tendencjami sekularyzacyjnymi sproblematyzowanie doświadczenia religijnego. To wszystko wydarza się przed Norwidem lub w latach jego młodości. Poeta zdawał sobie sprawę $z$ oświeceniowych i późniejszych tendencji ateizacyjnych; traktował je wszakże jako reakcję na nadużywanie religii w polityce i uznawał za coś sprzecznego z natura człowieka. Pisał np. w Zarysach z Rzymu:

I oto była doba WIARY bez miłosierdzia i nadziei - i MIŁOŚCI doba, tak pamiętna z najabsolutniejszego niedowiarstwa, a dziś jesteśmy o NADZIEI, lecz - ile dotąd sądzić można - zbyteczną wi a ra nie grzeszymy, a zaś miłoś ci, śmiało powiem, iż brak dość jest widoczny. [PW-7 13]

Norwid nie roztrząsał projektów filozoficznych znajdujących się w tle sekularyzacji; więcej uwagi poświęcił im Adam Mickiewicz w prelekcjach paryskich. W latach

ry europejskiej” (za S. Brzozowskim), o czasie, w którym porządek nauki rozchodził się z porządkiem „świata wewnętrznego człowieka”, z czym łączyło się rosnące poczucie wydziedziczenia ze świata. Zob. też A. B ed na r e k-B o hdzi e w i c z, Homo capax, capax hominis. $Z$ problematyki antropologicznej w późnej twórczości Adama Mickiewicza. Gdańsk 2019.

21 Novali s, Henryk von Ofterdingen. Przeł., oprac. E. Szy ma ni, W. Ku ni cki. Wrocław-Kraków 2003, s. 12-13. BN II 247. 
dojrzałych - na co wielokrotnie wskazywali badacze - autorowi Vade-mecum towarzyszył, w osobności, Baudelaire. Obaj żyli w Paryżu, oddychali tą samą atmosferą kulturową i duchowa, zrekonstruowaną przez Waltera Benjamina w Pasażach. Byli jednak inni.

Jak pisał Hugo Friedrich, w przypadku francuskiego poety mamy do czynienia z twórczością powstająca na ruinach chrześcijaństwa: „Baudelaire jest nie do pomyślenia bez chrystianizmu. Ale nie jest już chrześcijaninem" ${ }^{22}$. Jego literacki świat zawiera motywy i idee o charakterze religijnym, nie składające się wszakże w religijną całość. Przede wszystkim nie gwarantują one zbawienia - raczej stanowią język pozwalający mówić o nowoczesności i jej doświadczeniu. Baudelaire przyjmował np. istnienie grzechu pierworodnego, niezbędne mu do akcentowania skażenia natury ludzkiej, ciążącego na człowieku przekleństwa. U poety pojawiał się specyficzny satanizm łączący się $\mathbf{z}$ wizją zła idealnego, przeciwstawianego złu banalnemu, zwierzęcemu, a także $z$ buntem metafizycznym (w rozumieniu Alberta Camusa). Baudelaire szuka duchowości i nieosiągalnej, ,pustej” idealności, jest rozdarty między tym, co materialne, a tym, co idealne, duchowe; miejsce mistyki zajmuje u niego sztuka moc wyobraźni - dająca człowiekowi nadzieję ocalenia, ważniejsza nawet niż wiara w sztuce religijnej: „Gdyby [...] Bóg nie istniał, religia i tak byłaby Święta i Boska. Bóg jest jedyną istotą, która aby panować, nie musi nawet istnieć. To, co duch stworzył, jest żywsze od materii”"23. Transcendencja okazuje się wszakże niedostępna w czasach poety, pozostała wyłącznie pamięć o niej. Za taki stan rzeczy odpowiadaja postęp cywilizacji oraz procesy demokratyzacyjne.

Po tym obszernym, acz niezbędnym wprowadzeniu pora zapytać o autora Pierścienia wielkiej damy, o jego religijność.

Potwierdzenie zarysowanego tu ujęcia religijności naiwnej (w sensie Schillerowskim) przynosi korespondencja Norwida, stanowiąca swoisty dziennik hominis religiosi zmagającego się z przeciwnościami losu i znajdującego wsparcie w Absolucie. Ale czy owa naiwność to na pewno jedyne możliwe odczytanie? I czy prywatna religijność poety nie kontrastuje zbytnio $\mathrm{z}$ jego rozpoznaniem XIX-wiecznej sfery publicznej, w której chrześcijaństwo podlega procesom erozyjnym? (Drugie pytanie odkładam wszakże na później.)

Norwid w swoich listach często wzywał Boga ${ }^{24}$. Można odnieść wrażenie, że stał się on uczestnikiem komunikacji, a nie tylko jej świadkiem. Twórca zdaje się mu w pełni ufać i poddawać jego wyrokom, podpowiedziom, zazwyczaj oczekując do-

H. F ri e d ri c h, Struktura nowoczesnej liryki. Od połowy XIX wieku do połowy XX wieku. Przekł., wstęp E. F eli k sia k. Warszawa 1978, s. 70-71. Zob. też J. A c qu i s to, The Fall Out of Redemption: Writing and Thinking Beyond Salvation in Baudelaire, Cioran, Fondane, Agamben, and Nancy. New York 2015.

23 Ch. Baudelaire, Race. W: Sztuka romantyczna. - Dzienniki poufne. Przekł., wstęp, przypisy A. Kijows ki. Warszawa 1971, s. 253.

24 Zob. A. Ka dyjew ska, „TEN, który jest wszystko, jest wszędzie”. O Bogu w pismach Cypriana Norwida. W zb.: Norwid a chrześcijaństwo. 
brych rozwiązań, czasem widząc karę, mającą zresztą źródło w sprawiedliwości Boskiej (w tekście [O modlitwie], a także w wierszu Monolog poeta pisze o umiejętności właściwego formułowania próśb w modlitwie). Autor Vade-mecum żywi przekonanie, że egzystencja rozgrywa się na oczach Stwórcy: w obustronnym zrozumieniu, dialogu toczonym przy oczywistym uznaniu wielorakiej i zupełnej przewagi jednej ze stron, nacechowanej miłosierdziem, zasługującej wyłącznie na miłość, traktowanej przez grzesznika - byt niesamodzielny, jakim jest człowiek - z pokora (Modlitwa). Z listów Norwida wyłania się obraz życia jako wędrówki, pielgrzymki wiodącej przez czas ku wieczności. Autor Vade-mecum przyjmuje, że Bóg niejako użycza nam nas samych, że pracujemy i czekamy na paruzję, pamiętając, iż wszystko, co było, zostanie osądzone, a na zbawienie trzeba zasłużyć. Zdaniem poety, Chrystus ciaggle realizuje swoją misję w świecie, przyjmuje śmierć na krzyżu, broni prawdy - odprawia „Ms zę wi e c z ną” (PW-9 60). Celem człowieka jest uczestnictwo w niej. Norwid pisze o uwewnętrznieniu wiary, dającej spokój i zarazem pozwalającej na udział $\mathrm{w}$ zmaganiach $\mathrm{z}$ losem i światem. Chrześcijaństwo obejmuje według poety - powinno obejmować - zarówno życie indywidualne (wewnętrzne), jak i społeczne, przy czym to pierwsze zajmuje więcej miejsca w refleksji twórcy. Norwidowska formuła Opatrzności - w historii, jak powiada poeta, nieustannie przejawia się „twórcza Przedwiecznego [...] ręka” (PW-9 412) - zakłada wszakże istnienie wolnej woli i związanych $z$ tym konsekwencji ${ }^{25}$.

Szczególnie widoczny jest resentymentalny - wręcz modelowo nietzscheański aspekt wiary Norwida ${ }^{26}$. Do Józefa Bohdana Zaleskiego pisze poeta o autoprezentacji Boga:

Kiedy [...] Przedwieczny usta swoje otworzył, aby dać się znać człowiekowi w historii, zaraz wypowiedział i ostrzegł, że poznają Go właśnie po tym, iż nie jest wcale Bogiem des gros bataillons des Pharaons, ale owszem Bogiem uciśnionych, bezbronnych i ku wolności tułających się. [PW-9 398]

Podobna perspektywa pojawia się we wczesnym wierszu zatytułowanym Siero$t y^{27}$. Zapewne tym, co ma chronić wiare przed idiosynkrazjami, jest Norwidowska refleksja na temat cierpienia i męczeństwa jako udziału w pasji Chrystusa. W miarę upływu czasu wątek resentymentalny - łączący się z poczuciem rosnącej samotności oraz skazania na tułactwo i różne przeciwności życiowe - splata się u poety z coraz wyraźniejszą krytyką cywilizacji, nowoczesności; zarazem poeta krytykuje polską, wciąż feudalną anachroniczność i ukazuje Polaków jako naród traktujący chrześcijaństwo powierzchownie, daleki od chrześcijańskich ideałów.

Znamienne, że język, którego Norwid używa w związku z wprowadzeniem religii do sfery publicznej, jest inny niż ten, którym posługiwał się Mickiewicz, pragnąc przede wszystkim zmienić relacje między narodami a państwami (eksponując też relację między ludem a władcami). Ów język odznacza się jakby zmniejszonym, choć przecież podstawowym zasięgiem oddziaływania. Czytamy np.: ,jeżeli historia

Zob. A. D u naj s ki: Norwid wobec tradycji teologicznej. „Studia Norwidiana” t. 8 (1990), s. 15 n.; Teologiczne implikacje historyzmu Norwida. W zb.: Norwid wobec historii. Red. E. C h le b o w s k a, Ł. Niewcza s. Lublin 2014, s. 135 n.

26 Zob. J. Trzn adel, Czytanie Norwida. Próby. Warszawa 1978, s. 293 n.

27 Zob. S. S a w i c k i, „Nie są nasze - pieśni nasze”. O poezji religijnej Norwida. W: Wartość- sacrumNorwid. Studia i szkice aksjologicznoliterackie. Lublin 1994, s. 181 n. 
trwa po Chrześcijaństwa przyjściu, to ku temu trwa, aby społeczne miłowanie i ponoszenie wzajemne brzemion w arcydzieło widome, organiczne i całe urobiły się" (PW-9 414). To wizja nie rewolucyjna, dotycząca historii przez duże H, jak u Mickiewicza, lecz moralna, związana z byciem pośród ludzi i z czynieniem dobra. Polityka międzynarodowa bądź kwestie społeczne, oczywiście naznaczone moralnym językiem religijnym, są rozpatrywane przez Norwida także pragmatycznie; ta pierwsza powinna się opierać na założeniach realistycznych, uporządkowanie tych drugich stanowi warunek trwania i rozwoju narodu. Chrześcijański moralista zbliża się tu do pozytywistycznych organiczników, choć zarazem jest daleki od - pojawiającej się np. u Herberta Spencera - biologicznej wizji społeczeństwa (zapewne potraktowałby ją jako redukcjonistyczną) ${ }^{28}$.

W rozmaitych sytuacjach Norwid określa siebie jako chrześcijanina (wyróżnia też wiele zjawisk określonych tym epitetem), rzadziej jako katolika ${ }^{29}$. Być może chrześcijaństwo stanowi dla niego formułę o bardziej uniwersalnym charakterze. W korespondencji pojawia się również wzmianka o starszeństwie chrześcijaństwa nad katechizmem. Czas pierwszych chrześcijan jest dla poety naznaczony szczególnym sensem, choć nie stanowi retrotopijnej pokusy - wyzwaniem sa bowiem teraźniejszość i przyszłość. Norwid przyjmuje wizję postępu wiary. Oto fragment z listu do Teofila Lenartowicza:

cofać się w owe czasy pierwszego trudu nie ma, albowiem wcale się cofać nie może, kto w prawdzie jest, tylko iść musi ciągle naprzód. A powiadam Ci, iż u fa m JA, iż tamta epoka w Europie skończona jest, i że dziś idzie o to, aby prawda tak zwyciężyła wszelką ponętę świeckiego wytworu i bogactwa, i władzy, jako ongi wszelki niedostatek, grubość i ubóstwo, i poniżenie. [PW-8 414]

To bardzo istotny fragment dla podjętych tu rozważań. Z jednej strony, pokazuje on, jak poeta przedefiniowuje kluczowe słowa epoki, wydobywajac ich prawdziwe znaczenia (podobnie postępował Mickiewicz); w tym przypadku chodzi o słowo „postęp”, mające obrazować rozwój duchowości i moralności, a nie ruch cywilizacyjny w nowoczesnym rozumieniu (ów rozwój moralny autor Vade-mecum określa gdzie indziej jako przejście od męczeństwa do obowiązku ${ }^{30}$ ). $Z$ drugiej unaocznia, że Norwid w specyficzny sposób postrzega zadanie chrześcijaństwa, związane zresztą ze wspomnianym gestem redefinicji. Pojawia się tu podobna perspektywa jak w cytowanej wypowiedzi z [Memoriału...]: trzeba odpowiedzieć na pokusy tego, co dotyczy sfery profanum, co wypiera religie, ogranicza sferę jej panowania i staje się znaczacca alternatywą dla chrześcijaństwa.

Czasem Norwid cytuje w listach Biblię, szukając w niej odpowiedzi na nurtujące go kwestie i traktując ją jako drogowskaz moralny ${ }^{31}$. Powołuje się również na

O stosunku poety do pozytywizmu pisze J. Ma ci eje wski (Cyprian Norwid. Warszawa 1992, s. 121 n.).

29 Zob. T. Kor py s z, „Chrześcijanin” $w$ pismach Cypriana Norwida. W zb.: Norwid a chrześcijaństwo.

30 Zob. A. D u naj ski, Chrześcijańska interpretacja dziejów $w$ pismach Cypriana Norwida. Lublin 1985, s. 171 n. - A. van Nieukerken, Norwid i scjentyzm - konteksty komparatystyczne (August Comte, Pierre-Joseph Proudhon). W zb.: O Norwidzie komparatystycznie. Red. M. Si w i e c. Kraków 2009, s. 13 n.

31 Zob. A. Merdas, Łuk przymierza, s. 29 n. - M. E. Rogow ska, „Biblia” w listach Norwida. W zb.: Norwid: listy, listy... Red. Ł. Ni ew c za s. Lublin 2017, s. $101 \mathrm{n}$. 
świętych Kościoła. Nakazuje słuchać proroctw, modlić się, spowiadać, przyjmować sakrament komunii, korzystać z katechizmu, szanować męczeństwo (choć krytykuje Polaków, którzy - bez wiary i myśli - na męczeństwie poprzestaja; według Norwida postęp moralny wiedzie do stanu, w którym nie będzie ono już potrzebne). Twórca - choć sprzeciwia się życiu kontemplacyjnemu - myśli o staniu się zakonnikiem, podejmuje nieudana próbę wstapienia do zakonu księży zmartwychwstańców. Wielokrotnie powtarza, że wzorem człowieczeństwa jest Chrystus, Bóg-człowiek, którego jednak nie można zredukować do człowieka - granica boskości nie daje się przecież przekroczyć. Transcendencja okazuje się tym, co zewnętrzne wobec ludzi, których celem, jak pisze poeta, powinno się stać „Z-wolenie” z jej zamiarami, wpisanie się w wyższa, zewnętrzną perspektywę (można w takim ujęciu widzieć wpływ tomizmu).

Norwid przedstawia się jako ultramontanin, w pełni wierzący w Kościół i papiestwo. W związku z tym potępia wszelkie sekciarstwo, postrzegając $\mathrm{w}$ nim złe tendencje partykularne, tytaniczne i narcystyczne, czego przykładem niech będzie polemika z towiańczykami. Zarazem, inaczej niż XIX-wieczni ultramontanie, ceni demokracje parlamentarną ${ }^{32}$. Watek ten pozostawiam jednak na boku - ma on bowiem swoje opracowania i nie łączy się bezpośrednio z podjętym tu problemem ${ }^{33}$. Wspomnę tylko, że Norwid krytykuje praktyki kościelne i praktyki księży, które uznaje za złe; są dla niego upadkiem - czy raczej potknięciem się - ducha chrześcijańskiego, co nie zmienia wszakże nastawienia poety do samej instytucji (ludzi dobra widzi on także poza Kościołem) ${ }^{34}$. Bez watpienia autor Vade-mecum jest przeciwnikiem dewocji, purytanizmu i faryzeizmu (Fraszka 〈!〉 [II], Fraszka 〈!〉 III); w Notatkach $z$ mitologii dostrzega w religiach proces „skorupienia” i związaną z tym konieczność powrotu do źródeł. Nie formułuje jednak tak radykalnego wątku jak Mickiewiczowska, zawarta w prelekcjach paryskich, krytyka „Kościoła urzędowego”, za którą stoi przekonanie o wyczerpaniu się dawnej formuły wiary i o konieczności wypracowania nowej formuły - zresztą dla autora Bransoletki Kościół to najczęściej nie tylko instytucja, lecz także wspólnota wiernych, zakorzeniona w stanowiącej źródło życia transcendencji ${ }^{35}$. Poeta często broni Kościoła i papiestwa przed stawianymi im zarzutami. Dla podjętych tu rozważań znaczące mogą się wszakże

Zob. R. Z a ją c z k ow s ki, „Głos prawdy i sumienie”. Kościót w pismach Cypriana Norwida. Wroclaw 1998, s. 139.

Zob. A. D u n a j s ki, Kościót w epistolarnych aluzjach Norwida. W zb.: Norwid: listy, listy..., s. 159 n. Sprawa stosunku poety do doktryny Kościoła katolickiego wydaje się skomplikowana i wymaga osobnego rozpatrzenia, zwłaszcza przy zwróceniu uwagi na powstające w czasach Norwida encykliki papieskie. Odwołując się do ujęcia T. Polak a (System kościelny, czyli Przewagi pana K. Poznań 2020, s. 16 n.), który wskazuje na tkwiące w jądrze chrześcijaństwa dwie sprzeczne i zarazem dopełniające się tendencje: anarchiczność (związaną z myślą Jezusa) oraz systemowość (związaną $\mathrm{z}$ instytucją oraz doktryną), należałoby umieścić autora Vade-mecum w pobliżu anarchiczności, choć bez wątpienia innej niż ta charakterystyczna dla romantyków. Przede wszystkim warto zapytać, w jakim stopniu eksponowana przez Norwida wizja Chrystusa pracującego w świecie „tu i teraz” mieści się w ramach ortodoksji katolickiej - szczególnie w jej XIX-wiecznym wymiarze.

Zob. Zajaczkowski, op. cit.

Zob. Piechal, op. cit., s. 176 n. 
okazać słowa krytyki podkreślające skalę kryzysu - właśnie kryzysu! - XIX-wiecznego chrześcijaństwa. Norwid wydobywa różne jego aspekty. Stwierdza np.:

Spanoszyli się Chrześcijanie, czując lub wiedząc, że dziewiętnaście wieków prawdy daje im Bożą prawdy moc. [...]. Mówią sobie albo nie mówią, ale poczuwają się, że są przez wieków dziewiętnaście wyswobodzeni od tych pierwszych usposobień naiwnych chrześcijańskich, które sprawowały ludzkością. [PW-9 256]

Tego typu wypowiedzi jest oczywiście w listach poety więcej. W dość radykalnej formie krytykuje on upadłe XIX-wieczne chrześcijaństwo także w Fulminancie.

Zwróćmy uwagę na pojawiającą się w myśleniu Norwida aporię. Otóż z jednej strony - jak o tym była mowa - odnotowuje on postęp dokonujący się w wymiarze duchowym i moralnym, wskazując na specyfikę XIX-wiecznego chrześcijaństwa, z drugiej natomiast pisze o kryzysie współczesności, za który odpowiadają - jak zobaczymy za chwile - m.in. procesy cywilizacyjne, sprawiające, że ludzie odstępują od swojego religijnego powołania. A przecież Kościół, zdaniem poety, powinien zarówno nauczać, jak i wojować, rozszerzać swoje panowanie, a zwłaszcza czynnie angażować się w obronę uciskanych.

Pomimo zlokalizowania omawianych tu zjawisk - są one powiązane $z$ adresatem listów (uderza np. szczególnie wyrazista konstrukcja ,ja” jako człowieka religijnego w listach do Marii Trębickiej), z okolicznościami, w których listy te były pisane (co ciekawe, w miare upływu czasu coraz mniej w korespondencji poety wyrażanego przekonania o Boskiej opiece, wraca ono dopiero w drugiej połowie lat siedemdziesiątych XIX wieku), a także $z$ dynamiką łączącą się $z$ odkrywaniem bolączek nowoczesności - w listach Norwida pojawia się autentyczny i spójny obraz tradycjonalistycznego człowieka religijnego, człowieka żyjącego w skończoności i przekonanego, że jest ona zakorzeniona w nieskończoności, pragnącego wejść w dziejący się proces sensu religijnego, ujawniającej się prawdy, i twórczo w nim uczestniczyć.

Wracam do sprawy religijności Norwida w dotychczasowych badaniach. Inne ujęcie problemu niż to pokazujące jej naiwny - w sensie Schillerowskim - charakter można znaleźć w książce Arenta van Nieukerkena Perspektywiczność sacrum ${ }^{36}$. Już w poprzedniej monografii - Ironiczny konceptyzm - w której Norwid wyrasta na patrona nurtu metafizycznego polskiej poezji modernistycznej, badacz wyszedł z założenia, że poezja ta powstaje w kontekście dokonującego się w nowoczesności rozpadu teologicznej wizji świata, w kontekście „odczarowania” świata w związku z tryumfem nauki, rozejściem się porządku doświadczenia ludzkiego i scjentystycznego ${ }^{37}$. Zadaniem poetów tego nurtu, również autora Vade-mecum, stała się próba integracji owych porządków, widoczna w praktyce literackiej ironicznego konceptyzmu, u Norwida także w zwrocie do archaiki literackiej wspierającej obronę coraz

A. va n Ni e u kerken, Perspektywiczność sacrum. Szkice o Norwidowskim romantyzmie. Warszawa 2007.

37 Zob. M. Gau chet, Le Désenchantement du monde. Une histoire politique de la religion. Paris 1985, s. 133 n. 
wyraźniej anachronicznego światopoglądu. Twórca okazuje się w ten sposób poetą religijnej pewności żyjącym w czasie niepewności. Jak zauważa badacz:

By złagodzić osamotnienie ,ja” w domenie „obiektywnych” praw nauk przyrodniczych i przezwyciężyć dychotomię między „realnym” światem a dziedziną sztuki, poezja wynalazła strategie uznające zasadność tych praw, a równocześnie dopasowujące ich konsekwencje do potrzeb ludzkich ${ }^{38}$.

W Perspektywiczności sacrum van Nieukerken pokazuje, jak Norwid staje się poetą czasu marnego, opisywanego przez Martina Heideggera w związku z lektura Hölderlina i Rilkego. Według badacza Norwid pisze o tajemnicy przekraczającej język, pisze więc w pewnej perspektywie, pośród innych perspektyw, i w ten sposób otwiera swoją literaturę na to, co nieuchwytne. To fragmentaryczność - przybliżenie - ma odsyłać do pełni. Znajdujemy się więc w sferze wspomnianego już toposu przesłoniętego widzenia, znanego $z$ listu św. Pawła ${ }^{39}$.

Jak sygnalizowałem, narzędzi postsekularnych do lektury autora Vade-mecum użyła Magdalena Siwiec. U poety zajmuje ja jednak bardziej problematyka moralna niż religijna. Siwiec dostrzega pojawiające się u Norwida rozpoznanie tendencji sekularyzacyjnych jego współczesności. Uwzględnia m.in. wiersz [Do Ludwika Nabielaka]. Postscriptum, dający ironiczna wizję wyobrażonej desakralizacji Europy, podkreślając przy tym ambiwalentny stosunek Norwida do nowoczesnej cywilizacji (pisała o nim Zofia Stefanowska, pokazując pozycję poety „wieku kupieckiego i przemysłowego" jako mieszczacą się w jej obrębie, uwzględniająca konieczność procesów dziejowych, a nawet ich po części pozytywny efekt, i zarazem poddająca je krytyce ${ }^{40}$ ). Dla Siwiec bezproblemowo postsekularny twórca to Baudelaire - z powodu, o którym już wspomniałem, cytując Friedricha: poeta posługuje się językiem religijnym pozbawionym religijnego kontekstu; jest dziedzicem myśli oświeceniowej, a jednocześnie poszukuje prawd $\mathrm{w}$ religii, zaciera granicę oddzielająca sacrum i profanum. W związku z Norwidem badaczka zwraca uwagę na fragmenty jego dzieła, w których pojawia się opozycja między skostniała formą religijna - dogmatyczną, instytucjonalną - a życiem; szczególnie mocno brzmi w tym kontekście fragment listu na temat potwierdzenia przekonań: „nie książką i literą, i dedukcjami Chrystianizmu, ale całym sobą: sumieniem, sercem, żołądkiem, nerwami, frakiem [...]" (PW-8 111).

Jak czytamy: „etyka Norwida oparta na wartościach chrześcijańskich jest związana przede wszystkim $z$ wyjściem ku człowiekowi poza dogmatem, szukaniem sacrum rozproszonego w świecie i dopełnianiem "braku"" 41 . Tak, etyka ta łączy się z „szukaniem sacrum rozproszonego w świecie i dopełnianiem "braku" - owo szukanie nie dokonuje się jednak poza dogmatem, co więcej: nie dokonuje się też poza Kościołem. To zresztą nie tylko szukanie, ale również performowanie, oczywiście specyficzne, odnajdujące się na drodze naśladowania Chrystusa, mające w nim swoje źródło. Norwid, jak pisze Siwiec, uwzględnia nową rzeczywistość współczes-

A. van Ni eukerken, Ironiczny konceptyzm. Nowoczesna polska poezja metafizyczna $w$ kontekście anglosaskiego modernizmu. Kraków 1998, s. 16. Do kwestii tej badacz powraca też w artykule Norwid, Heine, Gautier i poczatki modernizmu („Litteraria Copernicana” 2015, nr 2, s. 115 n.).

Z. S t e fa n ow s ka, Pisarz wieku kupieckiego i przemysłowego. W: Strona romantyków, s. 5 n.

M. Siwi e c, Norwid-Baudelaire: profanacje. W zb.: O Norwidzie komparatystycznie, s. $129 \mathrm{n}$. 
nego mu świata, ale pragnie ją wchłonąć w obręb chrześcijaństwa. Źródłem moralnym nie jest dla poety podmiotowość ludzka, lecz transcendencja.

Czy istnieje sprzeczność między stanowiskiem akcentującym schillerowską naiwność religijności Norwida a stanowiskiem, które ową religijność problematyzuje i podkreśla związany $\mathrm{z}$ nią wysiłek, napięcia i pęknięcia? W kontekście postawionego już pytania o to, czy Norwid mógł istnieć poza episteme swojego czasu, wypada zauważyć, że drugie stanowisko, osłabiające - w sensie Vattimowskim ${ }^{42}$ formułę religijności w poezji Norwida, wpisuje się właśnie w episteme drugiej połowy XIX wieku. Z pozoru wspomniana sprzeczność jest nieredukowalna. Ale podkreślam: $z$ pozoru. Po pierwsze, raz mowa (bardziej) o Norwidzie, o jego religijności, na dodatek deklarowanej, a raz (bardziej) o tekście Norwida i zapisanym w nim, a także rozważanym doświadczeniu religijnym. Pisanie okazuje się więc w tym przypadku praktyką może nie tyle dekonstrukcyjną, ile problematyzującą doświadczenie. Po wtóre, sam poeta wprowadza wykorzystana przez van Nieukerkena formułe paraboli, przybliżenia, wpisuje się zatem w topos „Videmus nunc per speculum [...]" i wskazuje na drogę od schillerowskiej sentymentalności po wtórną naiwność. Czytamy w Milczeniu:

co do działania przez pr zybliżen ie (approximative), te - wydawa mi się być najwłaściwiej doniosłym atrybutem ducha ludzkiego. Nie wiem, zaprawdę, czyli jest jaka forma działalności umysłowej odpowiedniejsza położeniu naszemu, jak przybliż en i e! Jesteśmy w każdym zmyśle i rozmyśle naszym otoczeni kryształem przezroczystym, ale u-obłędniającym poglądy nasze. Podobno że cokolwiek bądź czynimy, zagaja się albo uzupełnia przez przybliżen ni e. [PW-6 226-227]

O ile Novalis widział w zjawisku przybliżenia/oddalenia konsekwencję ludzkiego upadku, który dokonał się w nowoczesności, o tyle dla Norwida jest to konsekwencja grzechu pierworodnego i wygnania z raju. Jak sugerowałem, współczesność polskiego poety - naznaczona brakiem, niedopełnieniem - nie pozostaje bez wpływu na owo oddalenie. Podążmy obecnie tropem postsekularnym i przyjrzyjmy się bliżej warunkom jego zaistnienia.

Bez wątpienia, jak przekonująco pokazała Grażyna Halkiewicz-Sojak, Norwid jest poeta Całości ${ }^{43}$. Chodzi mi tu nie tylko o fragmentaryczny wgląd w całościowa tajemnicę istnienia (o czym pisał również van Nieukerken), lecz także o wizję Wielkiej Całości - uniwersum, u którego podstaw znajduje się chrześcijaństwo, porządkujące całość życia prywatnego i publicznego. Wypada raz jeszcze przywołać Novalisa, by uwyraźnić coś, co stanowi presupozycję Norwidowskiego ujęcia religii, głoszona przez polskiego poetę w sposób fragmentaryczny bądź metaforyczny, jak w liście do Bronisława Zaleskiego:

Rzym jest transcendentalnie-tenże sam, co był, gdy Zbawiciel (za Nerona) Piotrowi się na via Appia pokazał (Ojciec Ś $\langle$ wię)ty sam od niejakiego czasu spomina to i o tym lubi mawiać). Ostatnim Szlachci-

Zob. fascynująca, acz w moim przekonaniu rozmijającą się przez radykalizm ujęcia z myślą Norwida, rozprawę A. Ży w i oł k a Norwid wśród nihilistów. O „nihilologicznej” lekturze pism Cypriana Kamila Norwida (w zb.: Nihilizm i historia. Studia z literatury XIX i XX wieku. Red. M. S o k oł owski, J. Ławski. Białystok-Warszawa 2009).

43 G. Halkiewicz-Sojak, Wobec tajemnicy i prawdy. O Norwidowskich obrazach „całości”. Torun 1998. 
cem Rzymu (za Nerona) był Paw eł. Rzym tak pojmowany jest Ludom świata jego obiecaną Jerozalem, albowiem jest kartą historii u-transcendentnioną. [PW-10 19]

Chrześcijaństwo jest przez poetę traktowane jako podstawa uniwersalizmu europejskiego (i światowego), a symbolizujący je Rzym stanowi centrum Wielkiej Całości ${ }^{44}$. W jej obrębie - jak czytamy w liście dedykacyjnym Quidama - mieszczą się trzy tradycje: żydowska, grecka i rzymska. Norwid stawiając pytanie: „a łono Jej chrześcijańskie, czy myślisz, że w świadomej siebie rzeczywistości już tryumfalnie rozbłysło?” (PW-3 80), eksponuje procesualny charakter chrześcijaństwa ${ }^{45}$.

W Chrześcijaństwie, czyli Europie Novalis pisze o średniowieczu następująco:

Były to piękne, wspaniałe czasy, kiedy Europa była krajem chrześcijańskim, kiedy j e d e n chrześcijański lud zamieszkiwał tę część świata, nadając jej ludzki kształt; je den wielki wspólny interes łączył najbardziej odległe prowincje tego rozległego duchowego państwa. Nie mając wielkich świeckich posiadłości j e d en zwierzchnik kierował i jednoczył wielkie siły polityczne. Liczne bractwo, do którego każdy miał dostęp, bezpośrednio mu podlegało, spełniało jego wskazania i z zapałem dążyło do umocnienia jego dobroczynnej wiary ${ }^{46}$.

W średniowieczu chrześcijaństwo określało całość życia indywidualnego i wspólnotowego. To procesy modernizacyjne - jak uważa niemiecki romantyk - naruszyły tę całość, rozbijając ją na fragmenty i odczarowujac; w efekcie człowiek utracił święty zmysł łączący go $\mathrm{z}$ wymiarem sacrum. U Novalisa nie widać retrotopijnej nostalgii, choć mówi on o konieczności powrotu do źródeł. Nowoczesność, która odebrała Europie religię, wiedzie do odzyskania religii na wyższym etapie rozwoju, uwzględniającym także naukę i ratio. Trzeba jednak sprostać wyzwaniom czasu, w którym kontakt $\mathrm{z}$ absolutem staje się utrudniony.

Dla Norwida średniowiecze również stanowi epokę, w której fundamentem porządkującym całość istnienia było chrześcijaństwo. Wtedy też w szczególny sposób spełniony był wzorzec moralny „przez przytomność wszech-stronna miary najwznioślejszej - człowieka, przez uczucie obecności najprawdziwszego-człowieka, jaki był na planecie lub kiedykolwiek będzie" (PW-8 423-424). W swojej współczesności Norwid dostrzega rozchodzenie się porządku chrześcijaństwa i porządku nowoczesnej cywilizacji. W liście do Augusta Cieszkowskiego z 1871 roku (wydaje się, że datowanie jest tu istotne, bo z czasem poeta coraz wyraźniej rozpoznaje sekularyzacyjne tendencje nowoczesności), skupionym na stosunku do człowieka, w pewnym sensie ponawia pytanie Jeana-Jacques'a Rousseau:

Chrześcijańska moralność pozostała na stanowisku swoim pierwszym... a tymczasem społeczność chrześcijańska i cywilizacja dodały: I. bogactwo i konieczność bogactwa i zbogacenia się; II. przemysł-ostentację; III. gwałty przyśpieszeń mechanicznych i komunik a cyj ny c h; IV. jaw no ść etc., etc., etc. Skoro zaś objęło się tyle żywiołów pierwotnemu ustrojowi chrześcijańskiego ciała obcych, MORALNOŚĆ... czy stosownie rozszerzyła się?? Czy w mo r a ln o ś ć - s połe c zną ona rozrosła się? [PW-9 478]

Zob. Merd a s, Ocalony wieniec, s. $175 \mathrm{n}$.

W związku z poematem pisze o tym R. Fi g guth (Chrześcijaństwo dla wszystkich. Parę słów nt. „Quidama” C. Norwida. „Studia Norwidiana” t. $37\langle 2019\rangle$ ).

N ovali s, Chrześcijaństwo, czyli Europa. W: Uczniowie z Sais. Proza filozoficzna - studia - fragmenty. Wybór, przekł., wstęp, przypisy J. Prok o pi u k. Warszawa 1984, s. 148. 
Pytanie to ma oczywiście wymiar retoryczny, jest przy tym fundamentalne i często powraca u Norwida. W swojej poezji twórca porusza temat sekularyzacji m.in. w ironizujacym cyklu Co stychać? I co poczać?:

\footnotetext{
Po wiekach legendowych przyszły historyczne:

Boski ogień zaprzestał być dziejów skazówką

(Natomiast tanie mamy zapałki chemiczne,

które ująwszy zręcznie, gdy obrócisz główka

I o obuwie potrzesz, wraz płomyk wybucha... [PW-3 630]
}

Norwid prowadzi krytyczną obserwację cywilizacji na różnych jej poziomach. Kwestie te zostały już opisane, dlatego poprzestaję na syntetycznym omówieniu zagadnienia. Poeta kładzie nacisk na instrumentalny charakter kształtującej się cywilizacji, „Z-użyteczniającej” - jak konstatuje w Ostatniej z bajek - to, co jest do „Z-użytecznienia”. Świat podporządkowany praktyczności grozi według Norwida barbarzyństwem. W liście do Cieszkowskiego z 1871 roku czytamy:

Humanitarnego we wszystkim kształcenia się całe to praktyczne i realn e (jak nazywają dzisiaj) pokolenie zaniechało było na wiarę materialnych filozofików, ucząc się specjalnostek mechanicznych... aż oto jednego razu Historia głosem wielkim zapytała o LUDZI! - Zapytała owego, który sprzedał był wielkie tradycje prac za mechaniczne uzdolnienia do robienia watpliwotrwałych pieniędzy... zapytała go (mówię): „Co zrobiłeś, Kainie, z trupem brata twego, C zło wi e k a?!”... - I znalazłoż się też dużo lu dzi? - i znalazłże się c złowi ek w tej Europie?... [PW-9 477]

Wydaje się, że w krytyce cywilizacji doszło u poety do pewnego przesunięcia w stosunku do romantyków. O ile ci kładli nacisk na cywilizacyjną racjonalność i materialność, o tyle Norwid krytykuje jedno z ważnych pojęć swojego czasu: utylitaryzm, choć zarazem - w zgodzie $z$ ambiwalentnym postrzeganiem nowoczesności - przyjmuje jego wartość we własnym rozumieniu, łączącym się z perspektywą religijną i moralną. Utylitaryzm współczesności poety okazuje się antyhumanitarny. Podkreślam tę kwestię, ponieważ tym, na co wskazuje on w związku z desakralizacją świata, jest właśnie upadek moralności. W ujęciu Norwida cywilizacja o nastawieniu instrumentalnym odznacza się ponadto rozpadem całości oraz podporządkowanym specjalizacji rozwojem jednostronnym, ograniczającym człowieka $^{47}$.

Współczesną sobie cywilizację Norwid przedstawia m.in. w zbiorze Vade-mecum, będącym zapisem podróży przez piekło XIX wieku (co znamienne, aluzyjnie odnosząc się do Dantego), świadectwem desakralizacji świata, wyczerpania jego duchowości zarówno w wymiarze profanacji sacrum, jak i, także w tym przypadku, zwłaszcza w perspektywie moralnej ${ }^{48}$. Kwestia ta powraca m.in. w Pięciu zarysach: poeta ukazuje świat, w którym ludzie przestają wierzyć, postrzegając w Biblii fałsz; wiąże się $\mathrm{z}$ tym zanik twórczości i upadek moralności. Do głosu dochodzi ludzka, tytaniczna, narcystyczna podmiotowość. Marek Adamiec celnie zaproponował w od-

47 Zob. M. W ą s ikow s ka, Cywilizacja w pismach Cypriana Norwida. W zb.: Norwid - spotkania kultur. Red. E. Chle bow s ka. Lublin 2015. Zob. też J. F e rt, Poeta sumienia. Rzecz o twórczości Norwida. Lublin 1993, s. 107 n.

48 Zob. A. Kuciak, Dante romantyków. Recepcja „Boskiej Komedii” u Mickiewicza, Stowackiego, Krasińskiego i Norwida. Poznań 2003, s. 178 n. 
niesieniu do Norwidowskiego ujęcia współczesności formułę „śsiat na opak”49. W miarę upływu czasu coraz częściej pojawiają się u Norwida tak radykalne stwierdzenia na temat własnej epoki jak następująca wypowiedź:

Cała Epoka jest małpa sprzedająca wszystko za pieniądze i nikczemna ze wszech miar. Człowiek u niej szanowny jest ten, który jest wygodny i dopóki wygodny - sądu w niczym - smak uliczny - lenistwo ducha i osłabienie serca, a skora nerwów pochopność - oto obraz tej małpy. [PW-9 254]

Przywołam tu jeszcze nowele Cywilizacja, która w alegoryczny sposób przedstawia procesy zmieniające świat XIX wieku, poddające go również sekularyzacji. Jak znakomicie rozpoznała to Ewangelina Skalińska, poeta wykorzystuje biblijna opowieść o arce Noego i potopie jako ramę dla ukazanej historii ${ }^{50}$. U Norwida wszystko okazuje się jednak inne niż w tamtej opowieści, zdesakralizowane (inaczej też niż w Legendzie Krasińskiego, do której Norwid nawiązuje; tam parowiec również symbolizuje piekielną cywilizację, ale płynący nim Polacy współtworzą historię święta). Parowiec „Cywilizacja” - w opozycji do żaglowca, pełnego poezji, wzniosłości, symbolu dawnej Wielkiej Całości - to twór epoki, która zmęczonemu pozwala na odpoczynek i gwarantuje szybkość ${ }^{51}$. Odznacza się czystością i porządkiem, a także władzą prawa - słowem: praktycznością wymierzoną przeciw żywiołowi natury. Nie tworzy wszakże prawdziwej wspólnoty, podróżujących łączy jedynie pokład. Sa to $\mathrm{m}$.in. kpiący $\mathrm{z}$ wiary ateusze oraz misjonarze skrywający się $\mathrm{z}$ obawy przed wzbudzeniem śmiechu; aktorzy w teatrze nowoczesności: samotni, udający coś, milczący. Stopniowo psuje się jakość podróży, która kończy się katastrofą w lodzie. Płynący są zagubieni, pojawiają się bluźnierstwa, załoga pije, kapitan nie dopuszcza duchownego do modlitwy. Bohater-narrator pyta:

Myśl żywotna w ludzkości byłażby tak mechaniczną pracą i tak źródłowej żadnej wnętrzności swojej nie mającą? Prawda jestże tylko ostatecznością wynikłą ze starcia się i wzajemnego odpychania jednostronnych humorów rozmawiajacych z soba o by w a te li? Ale sama przez się azali, powtarzam, prawda nie jest niczym, tylko czczością myślenia? tylko jestże ona jakoby tym miejscem na coś przypadkowego, i tą jakoby idealnie pojętą próżnią, o której się mawia w umiejętnościach, wiedząc wszelako, iż próżni nigdzie nie ma? Jednym słowem jestże więc prawda kłamstwem? [PW-6 55]

Tak wygląda Norwidowska wizja świata pozbawionego scalającego go świętego sensu (wzmianka o „czczości myślenia” może być aluzją do niemieckiej filozofii idealistycznej, oskarżanej w ten sposób o ateizm i nihilizm), wizja nowoczesnego państwa, które usuwa religię z życia publicznego ${ }^{52}$ i którego obywatele sami pozbywają się religii $z$ życia prywatnego.

Technika stanowi dla Norwida spektakularny aspekt nowoczesnej cywilizacji. Poeta zwraca uwage głównie na środki komunikacji - koleje i statki parowe, druk, telegraf - pytając retorycznie, na ile w rzeczywistości, a więc moralnie, zbliżają do siebie ludzi. Ceni postęp materialny, ale nie godzi się na jego fetyszyzację; cywili-

M. A d a m i e c, Cypriana Norwida „świat na opak”. W zb.: Cyprian Norwid. W setną rocznicę śmierci poety, s. $76 \mathrm{n}$.

E. Ska li ń s ka, Norwid - Dostojewski. Zbliżenia i rekonstrukcje. Warszawa 2014, s. 266 n.

51 Zob. W. Ra taj c z a k, List z butelki, czyli koniec epoki żaglowców. „Poznańskie Studia Polonistyczne. Seria Literacka” t. 4 (1997), s. 193 n.

52 To życie zostaje przez poetę przedstawione w obrazach salonu. Zob. Tr z n a d e 1, op. cit., s. 250 n. 
zacja nie rozwiązuje, zdaniem twórcy, wszystkich problemów człowieka, nie tylko duchowych, lecz i materialnych - ponadto rodzi nowe problemy. Norwid staje przy tym na stanowisku nie tyle jej odrzucenia (jak już wspomniałem, dostrzega także jej strony dodatnie, co widać znakomicie w opisanym przez Wiktora Weintrauba stosunku poety do Ameryki - kraju wolności, demokracji, ale zdesakralizowanym w nowoczesny sposób ${ }^{53}$ ), ile poddania jej zasadom chrześcijaństwa; ponadto widzi jej szczególną potrzebę w Polsce, której problem polega m.in. na anachroniczności.

Autor Vade-mecum wypracowuje projekt dopełnienia jednostronności nowoczesnej cywilizacji, scalenia jej fragmentów, odwrócenia tendencji instrumentalizacyjnych, powrotu do teocentryzmu, $z$ którym powinien przyjść prawdziwy humanizm (nie ma też u poety opozycji „rozum-wiara”) ${ }^{54}$. Do Karola Ruprechta pisze o konieczności cywilizacji i o związanych z nią wyzwaniach:

Jest to zaiste niemiłe, ale konieczne następstwo druku, pary, telegrafu i innych wielu rzeczy, przeciw którym - iż ogarnęły świat i że są owocem dokonanych poś wi ęceń pracy ludzkiej - przeciw którym, mówię, najgorętszym i najczystszym uczuciem serca nic zrobić nie można i w pewnej mierze nie godzi się. Że przeto owe następstwa każą wyzywać przyszłość bojem z a c z e p n y m, nie od por ny m, nie koniecznym, nie fatalnym i w owoce jałowym. [PW-9 116]

Nowoczesność stanowi dla chrześcijanina wyzwanie, przestrzeń szczególnej, niemal apostolskiej pracy. Co więcej, pisząc do Trębickiej o trwającej w świecie pracy Zbawiciela, Norwid powiada:

Zaiste [...] przyjść może chwila, w której jednego dnia zobaczymy naocznie każdy moment, w którym Zbawiciel gdzie pracuje... I wielce się zdziwimy, że tak blisko jest, służąc nam... Któż wie? azali np. fenomen jako daguerotypowy z góry nie oświeci nam kolorem Zbawicielowym wszystkich tych punktów nie uszanowanej pracy jego wkoło nas: będzie to ostatnim kryterium całego przemysłowego wydelepowania cywilizacji... zobaczymy, o ile mylę się, i w czym... [PW-8 214]

A zatem nowoczesność - jej wymiar cywilizacyjny - może się okazać nowym etapem realizacji chrześcijaństwa ${ }^{55}$. Zwróćmy uwagę: Norwid, inaczej niż Novalis, nie myśli o cyklu, w którym dokonuje się upadek; polski poeta traktuje czas jako skomplikowany splot tendencji wstecznych i progresywnych, oczywiście mając na względzie postęp moralny.

Aspektem cywilizacji najwyraźniej eksponowanym przez Norwida i budzacym jego silny sprzeciw jest liberalna, kapitalistyczna ekonomia, wiążąca się $z$ uroszczeniami nowoczesnego podmiotu, który zastępuje nią religię (w wierszu Syberie 〈PW-2 58〉 mowa o drugiej Syberii „pieniędzy i pracy”). Z jednej strony, chodzi

Zob. W. We in tr a u b, Norwid i Ameryka. Przeł. R. W e r p a c h ow s k i. „Studia Norwidiana” t. 14 (1996).

54 Zob. E. Ka sper s ki, Świat wartości Norwida. Warszawa 1981, s. 13 n. - Z. Tr oj a n ow ic z ow a, Ostatni spór romantyczny. Cyprian Norwid-Julian Klaczko. Warszawa 1981, s. 92 n. - Ł. Ni ew c z a s, „Stolica” - pęknięty obraz. „Studia Norwidiana” t. 26 (2008), s. 99 n. - S. Rz e p c zy ń s ki, Norwid a nowoczesność. W zb.: Romantyzm i nowoczesność. Red. M. Kuziak. Kraków 2009, s. $190 \mathrm{n}$.

55 W takim kierunku, uwzględniającym otwarcie poety na nowoczesną cywilizację, zmierza interpretacja Cywilizacji zaproponowana przez Z. Tr oj a n o w i c z o w ą ("Cywilizacja” Norwida. Próba nowej lektury. W: Romantyzm). 
o prace przemysłowa, tej poeta przeciwstawia rzemiosło ${ }^{56}$; $\mathrm{z}$ drugiej - o merkantylizację świata, wroga perspektywie religijnej, chrześcijańskiej (a więc też moralnej, ludzkiej), jak zostaje to ukazane w „Ad leones!”. Szczególnie boleśnie - co w związku z krytyką anachronizmów jest naznaczone ambiwalencją - próbę nowoczesnej ekonomii przechodzi, zdaniem twórcy, polski świat: wątek ten pojawia się np. w Aktorze. Do Franciszka Wężyka poeta pisze:

Ekonomiści [...] XIX-o wieku zapomnieli prawie, iż kamieniem filozoficznym pieniędzy nie złoto jest, ale D e kalog, ale Mojżeszowe „nie kradnij, nie pożądaj...” - ale, jednym słowem, Ideał w myśli Przedwiecznego zapisany i przed-położony człowieczeństwu przez kategorie z-Bożnych, historycznych ciał, ojczyzn (wielka to rzecz i mało z kim to mówić można). [PW-8 305]

Być może (nie da się bowiem wykluczyć ironiczności tej wypowiedzi) próbę ureligijnienia ekonomii poeta kreśli w następującym fragmencie listu do Antoniego Zaleskiego i Teofila Lenartowicza:

Kredy tem się zowie wiara w czasu, sił żywotnych i woli Bożej prawa. Pien niądz jest czasem, kredytem i działalnością ludzką. Ludzie czynni są ci, co nie zależą od mi ejs cow ości, ale miejs c ow ość zależy od nich. [PW-10 88]

W Pieśni społecznej czterech stronach krytyce poddany zostaje Zachód:

Gdzie jest pono wolne d r zewo

Ale człek mrze z głodu. [PW-3 345]

Norwid proponuje z pozoru bliski socjalistom, lecz umocowany w religii projekt ujęcia własności:

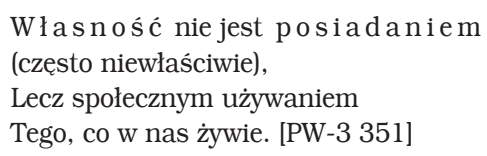

Własność musi mieć charakter moralny („Nie ma mienia bez sumien i a”, PW-3 352), nie powinna ulegać żądzy ani szaleństwu.

We fragmencie Co poczać? poeta zdaje się polemizować z pozytywistycznym projektem organicznikowskim, kładącym nacisk na patriotyzm gospodarczy:

Tak, zniszczonemu rzeknij narodowi,

By się zbogacał tylko jak najprędzej,

A złoto mając resztę postanowi,

Historii ustrój doda do pieniędzy.

Ucz go, by jednym krokiem się przerzucał

$Z$ fatalnych jatek dziejów do warsztatów,

Nauczysz, by się tak śmiał, jak zasmucał,

I zbawisz ludzkość... lecz automatów! [PW-3 632]

Piszę o tym szerzej w artykule Norwid i Marks. Dwie nowoczesności (w zb.: O Norwidzie komparatystycznie). Zob. też Fe r t, op. cit., s. 69 n. Norwid, będąc krytykiem kapitalizmu, nie mieści się jednak w zaproponowanej przez M. Löwy' e go i R. S a y re' a (Révolte et mélancolie. Le romantisme à contre-courant de la modernité. Paris 1992) formule antykapitalizmu romantycznego. Poeta krytykuje nowoczesność podobnie jak romantycy, ale w przeciwieństwie do nich nie szuka retrotopijnej iluzji. Traktuje swój czas i jego procesy jako wyzwanie moralne. 
To oczywiście krytyka fetyszyzmu ekonomii materialnej, Norwid przecież, jak wspominałem, wielokrotnie wypowiada się przeciw polskim anachronizmom, bluźnierstwu i bałwochwalstwu o rodowodzie feudalnym - odmiennym od bluźnierstwa i bałwochwalstwa nowoczesnego ([Dwie powieści]).

Poeta obserwuje otaczajacy go tygiel idei XIX wieku. W związku z tą kwestia można dostrzec ciekawe zjawisko, w szczególny sposób mieszczące się w perspektywie postsekularnej. Norwid bowiem - z jednej strony - przyjmuje fundamentalne idee porewolucyjnej nowoczesności, ale - z drugiej - odziera je $z$ pierwotnego rewolucyjnego i oświeceniowego kontekstu (jak pamiętamy, podobnie postępował $z$ formuła postępu, podobnie chciał traktować technikę i ekonomię...). Przekonuje, że chodzi o rozwinięcie zasad chrześcijaństwa (analogiczne sądy głosił też zresztą Mickiewicz); trzeba także pamiętać o widocznym w epoce splocie myśli socjalistycznej, utopijnej $z$ religią.

Norwid polemizuje $z$ koncepcjami, które mają wymiar ateistyczny czy utopijny (millenarystyczny) i zakładają rychłe rozwiązanie problemów społecznych i politycznych świata (jak wspomniałem, wyjątek stanowi twórczość powstała po Wiośnie Ludów, np. Psalmów-psalm) ${ }^{57}$. Te przecież - co wielokrotnie podkreśla autor Vade-mecum - wymagają długotrwałej ciężkiej pracy moralnej scalającej i ulepszającej świat (wiersze: Socjalizm, Harmonia, Specjalności, Saturnalia, Prac-czoło). Norwid krytykuje zatem mesjanizm, a także socjalizm ${ }^{58}$. Jak pamiętamy, nie godzi się na myśl, która ma źródło w roszczeniach podmiotowości, w jej tytanizmie i narcyzmie (bo przecież chodzi o to, by podążać „Nie z krzyżem Zbawiciela za sobą - ale z krzyżem s w o i m za Zbawicielem" (PW-3 471〉). Jest więc ogólnie przeciwnikiem rewolucji; uważa, że ma ona źródło w krzywdzie, ale nie widzi w niej sposobu na rozwiązanie problemów społecznych. Zmianę można wprowadzać, zdaniem Norwida, tylko z Bogiem ([Bądź wola twoja...]). W Promethidionie poeta podkreśla, że rozwój polega na pracy splecionej z miłością:

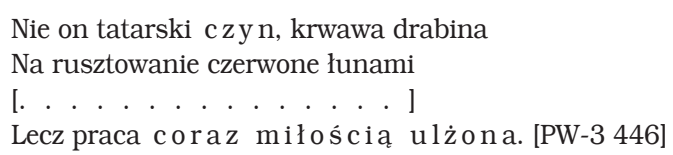

Męczeństwo, cenna praca duchowa, powinno zostać - zdaniem twórcy - „uniepotrzebnione" i zastapione obowiązkiem (Promethidion). Zarazem Norwid przyjmuje idee, które pojawiaja się na gruncie porewolucyjnej nowoczesności: równości, wolności, braterstwa, i redefiniuje je w kontekście religijnym. Tak np. w Niewoli, określając tytułowe zjawisko jako uznanie formy za cel (postawienie ciała ponad duchem), pisze: „Bo wolność tam jest, gdzie duch Pański czuwa” (PW-3 381). Poeta okazuje się zatem religijnym reformistą, przyjmującym, że za zmianą społeczną - oprócz wiary, fundamentu religijnego - muszą stać wysiłek

Zob. R. G a d a m s k a - S e r a fi n, „Czasy skończone!”? - Norwid a koncepcje „końca historii”. W zb.: Norwid wobec historii.

58 Zob. A. W ali c ki, Cyprian Norwid: trzy wątki myśli. W: Między filozofia, religia i polityka. Studia o myśli polskiej epoki romantyzmu. Warszawa 1983, s. 210 n. - M. In gl o t, „Socjalizm” Cypriana Norwida $w$ kontekście myśli historiozoficznej Augusta Cieszkowskiego i Zygmunta Krasińskiego. W: Drogami pielgrzyma. Studia i artykuły o twórczości „czwartego wieszcza”. Lublin 2007, s. 293 n. 
moralny, dobra wola i miłość. Zresztą, jak przekonuje, to Kościół zainspirował idee, które znalazły się u podstaw demokracji parlamentarnej ([O idei reprezentacji]). Władzę Norwid również definiuje moralnie i religijnie:

\author{
Rząd jest tylko sprawiedliwo ść, \\ Co nie-prawem karze; \\ Gromi nawet nieuczciwość, \\ Szanuje ołtarze. [PW-3 357]
}

W stanie kryzysu znajduje się według poety także XIX-wieczna sztuka: „Cała sztuka, nie wyjmując sztuki pisania, jest na całym świecie z-degradowana [...]" (PW-8 269). Dotknęły ją procesy nowoczesności związane z ekonomizacją i desakralizacją, prowadzace do pozbawienia wymiaru duchowego i moralnego. Kwestię tę porusza Norwid m.in. w noweli „Ad leones!”. Przypomnę opowiedzianą historię: artysta rzeźbiarz postanawia stworzyć dzieło o charakterze religijnym, przedstawiające męczeństwo pierwszych chrześcijan. Powstająca rzeźba zaczyna funkcjonować jako fakt społeczny - mówi się o niej, ogląda etapy jej powstawania. Artysta ulega naciskowi publiczności (zaprezentowanej zresztą w komiczny sposób), redukując wymiar religijny, później moralny, by w końcu zamienić swoje dzieło - pod wpływem sponsorującego Amerykanina, redaktora wielkiego dziennika - w rzeźbę zatytułowana Kapitalizacja; zdarzenie to zostaje przyrównane do wydania Jezusa przez Judasza za 30 srebrników. Być może - w związku z postacią sponsora - jest tu aluzja do kapitalizmu mającego w XIX wieku, zwłaszcza w Stanach Zjednoczonych, podbudowę religijną. Problem, jak zauważa Stefanowska, stanowi nie tylko sama decyzja artysty, lecz i sytuacja, w której nakłady na dzieło są dla twórcy nie do udźwignięcia, tak że potrzebuje on mecenasa. Dzieło musi więc stać się produktem funkcjonujaccym na rynku ${ }^{59}$. Wielokrotnie formułowane przez poetę uwagi na temat rozwoju powieści (np. Milczenie, Czas i prawda, Dziennik i epos, Na zgon poezji), wiodącego do produkcji sprzedających się masowo utworów, okazują się trafna intuicją rozpoznająca powstanie przemysłu kulturalnego dalekiego od religijnej moralności ${ }^{60}$.

O kryzysie sztuki - powiada Norwid - świadczy ponadto rozpad całości sztuki/ techniki, specjalizacja naruszająca fragment dawnej Wielkiej Całości kultury. Czytamy w epilogu Promethidiona:

Rozdzielenie eks p ozy cj i publicznych na ekspozycje, czyli wy s ta wy sztuk pięknych i rzemiosł albo przemysłu, jest najdoskonalszym dowodem, o ile sztuka dziś swej powinności nie wypełnia. Wystawa powinna być, przeciwnie, tak urządzona, ażeby od statuy pięknej do urny grobowej, do talerza, do szklanki pięknej, do kosza uplecionego pięknie, cała cyrkulacja idei pi ę k n a w czasie danym uwiadomioną była. [...] Dziś jest rozdział duszy z ciałem, czyli śmierć!... [PW-3 470]

Jak pamiętamy, wszelka jednostronność wiedzie - zdaniem Norwida - do barbarzyństwa. W Promethidionie poeta wprowadza swój wariant użyteczności, od-

Zob. Trznad el, op. cit., s. 42 n. - St e fa n ow s ka, Pisarz wieku kupieckiego i przemysłowego, s. $49 \mathrm{n}$.

60 Zob. M. Inglot, Norwid wobec powieści jako literatury popularnej swoich czasów. W: Drogami pielgrzyma, s. $101 \mathrm{n}$. 
mienny od krytykowanego utylitaryzmu epoki; sztuka ma wspierać pracę, nadawać jej wymiar moralny i w ten sposób przysłużyć się sprawie zbawienia.

Sztuka w ujęciu Norwida - inaczej niż u Baudelaire’a, który kładzie nacisk na nowoczesne doświadczenie (Malarz życia nowoczesnego) - ma źródło w wymiarze transcendencji. Polski poeta pozostaje po stronie platońskiej trójjedni piękna, dobra i prawdy, przy czym dodaje do niej miłość; autor Kwiatów zła zrywa z owa trójjednią. Sztuka ma z kolei stanowić źródło cywilizacji chrześcijańskiej. W tekście O sztuce (dla Polaków) czytamy: „s ztuka ekwacją jest postępu - postępu nawet mor aln e g o, o ile ten historii jest przedmiotem" (PW-6 341). I dalej:

W idealnym piękna uprawianiu leży pewne uczucie-wyżs ze go-porządku-rzeczy, ku któremu wznosząc się, jeżeli nareszcie u szczytów onego napotkanej prawdy nie może wziąść, to jedynie dlatego, iż człowiek wziąść sam nic nie może, co by mu pierw nie było dano wziąść. [PW-6 345]

Tak wygląda odpowiedź poety na dokonującą się w jego czasach desakralizację sztuki61.

Przedmiotem szczególnej polemiki Norwida, wymierzonej w nowoczesne procesy sekularyzacyjne, stała się koncepcja Darwina. Jak pokazuje Elżbieta Feliksiak, stosunek poety do Darwina ma swoja dynamikę ${ }^{62}$. Krytyka myśli ewolucjonistycznej pojawia się u autora Vade-mecum pod koniec lat pięćdziesiątych XIX wieku, nazwisko przyrodnika zostaje wspomniane pod koniec lat sześćdziesiątych; spór nasila się po 1871 roku, kiedy ukazuje się książka O pochodzeniu człowieka. Polemikę $z$ darwinizmem Norwid prowadzi ze stanowiska chrześcijaństwa, a więc kreacjonizmu - u jej podstaw znajduje się perspektywa moralna, mająca, zdaniem twórcy, określać także naukę. Pomijając niechęć poety do znamiennego dla ewolucjonizmu myślenia systemowego, wyeksponuję tu problem antropologiczny, stojący w centrum sporu. Norwid nie godzi się na pozbawienie człowieka jego godności, mającej źródło w Boskim geście stwórczym, a za takie pozbawienie uznaje wpisanie dziejów ludzkości w porządek naturalistycznej ewolucji (Assunta, Rzecz o wolności słowa, Naturalizm. (Spółczesny ekstrem〉). Ma ono odcinać człowieka nie tylko od transcendencji, ale i od kultury oraz tradycji, wprowadzać relatywistyczna i hedonistyczną etykę w miejsce maksymalizmu moralnego, pozwalającego mówić o szczególnej misji człowieka w kosmosie ${ }^{63}$. W liście do Ruprechta z 1867 roku poeta pisze, że „człowiek nigdy nie jest zwierzęciem istnym z tej przyczyny, iż człowiek jest zawsze obrazem i podobieństwem Boga żywego" (PW-9 314).

Ewolucjonizm darwinowski to w ujęciu Norwida raczej historiozofia niż przyrodoznawstwo. Odpowiedzią poety staje się konsekwentnie powracająca w jego utworach od końca lat pięćdziesiątych XIX wieku antropologia ukazująca człowie-

61 Zob. Trznade1, op. cit., s. 293 n.

62 Zob. E. Feli ks i a k, Poezja i myśl. Studia o Norwidzie. Lublin 2001, s. 144 n. Ponadto: P. Le h r -S pławiński, Darwin - Narwid - Norwid. W zb.: Dziewiętnastowieczność. Z poetyk polskich i rosyjskich XIX wieku. Red. E. Czaplejewicz, W. Grajewski. Wrocław 1988, s. 117 n. M. Ry gi i ls k a, „Dwa guziki”. Norwid i ewolucjonizm. Katowice 2011. - K. C i eśli k, Twórczość Cypriana Norwida a teorie ewolucjonizmu drugiej połowy XIX wieku. Warszawa 2017.

63 Zob. A. van Ni e uke rken, Postęp i myśl krytyczna u Norwida i Piotra Ławrowa. „Studia Norwidiana” t. 38 (2020), s. 59 n. 
ka jako zakorzenionego w transcendencji, jako byt duchowy, pielgrzyma wędrującego między upadkiem a odkupieniem, $z$ czym wiąże się wizja pierwotnej doskonałości - utraconej i odzyskiwanej. W ten sposób autor Vade-mecum pragnie ocalić (przywrócić) naznaczoną sakralnie wizję wielkiego łańcucha bytu, w którym człowiek stanowi centrum stworzenia: między światem przyrody a światem aniołów; wizja ta określa kosmos jako Wielką Całość, uporządkowaną i hierarchiczną. Człowiek jak pamiętamy $\mathrm{w}$ związku $\mathrm{z}$ obrazem poety wyłaniającym się $\mathrm{z}$ jego listów - jest przedstawiany przez Norwida w horyzoncie wyobraźni teologicznej, biblijnej (w kontekście postaci Mojżesza i Chrystusa). To „Boga sassiad” (Człowiek) obdarzony misją w świecie (kapłaństwem - nawet jeśli okazuje się ono „bezwiedne i niedojrzałe”, jak w wierszu Sfinks) ${ }^{64}$ i losem, na który składają się nacechowane moralnie doświadczenia, wyzwania. Poeta zwraca uwagę, że taka wizja człowieka w XIX wieku staje się ofiarą zapomnienia, ewentualnie powraca wbrew przesądom znamiennym dla współczesności. W liście do Mariana Sokołowskiego czytamy:

System Darwina jest tak miałki, że dziecko mogłoby go obalić (zwierzęta są tylko parabolic znymi braćmi naszymi) - ale system Darwina rozgłos swój ma dla tej wnętrznej społeczeństwa przyczyny, iż z kast się chrześcijańskie ciało nie wyjarzmiło. Jest to dyscyplina pokory filozoficznej w rudymentach dopiero założonej. [PW-10 53-54]

Powracamy zatem do rozpoznania słabości chrześcijaństwa XIX-wiecznego, odpowiedzialnej za ekspansje - zwłaszcza w sferze publicznej - sekularyzacji.

Jakie wnioski płyną z tych rozważań? Zebrałem tu zagadnienia, które mają w norwidologii swoje opracowanie, zarazem właśnie zebrane w całość wskazują na taką całość w refleksji poety - całość, próbę całości, utrzymaną w formule Taylorowskiego postsekularyzmu. Wiemy już, że Miłosz się mylił, pisząc o „zacnym” Norwidzie. Jego chrześcijaństwo nie jest w sensie Schillerowskim „naiwne”, kształtuje się wobec wyzwań i zagrożeń współczesności. Norwid diagnozuje zjawisko, które dzisiaj określamy mianem sekularyzacji świata. Za ciekawe wypada uznać rozróżnienie praktyki religijnej poety - precyzyjniej byłoby mówić o deklarowanej praktyce - i jego (również poetyckiej) refleksji religijnej. Kiedy ta pierwsza wydaje się, tak to ujmę, monologowa, druga staje się dialogiczna, przypomina o Taylorowskiej formule subtelnego języka; przykładem może być polemiczna w stosunku do nowoczesnej nauki i uwzględniająca ją Rzecz o wolności słowa. To tak, jakby Norwid na planie egzystencjalnym - nie pierwszy raz - budował sobie niszę chroniąca go przed nowoczesnym światem ${ }^{65}$, starał się ignorować jego zmiany. $Z$ kolei na planie pisarskim poeta stopniowo otwiera się na dyskursy nowoczesności, postrzega je jako konkurencję, a nawet zagrożenie dla chrześcijaństwa i usiłuje je odeprzeć. Strategia

64 Zob. W. Stróże w s ki, Filozofia człowieka $w$ „Vade-mecum” Cypriana Norwida. W zb.: Norwid a chrześcijaństwo. - A. D u n a j k ki, Teologiczny wymiar twórczości Norwida na przykładzie jego refleksji o pochodzeniu człowieka. W zb.: jw.

65 Piszę o tym szerzej w artykule Norwid i pejzaż nowoczesności. Wokół Paryża poety (,Studia Norwidiana"〈t. 32〉 2014). 
Norwida polega na próbie wchłonięcia nowoczesnej cywilizacji w obręb chrześcijaństwa; czasem gwałtowność filipik antycywilizacyjnych, ostrze ironii, może sugerować, że chodzi o jej odrzucenie, ale twórca ma do niej, jak już wspomniałem, stosunek ambiwalentny.

Dlaczego szczególnym przedmiotem krytyki Norwida stał się Darwin? Jak stwierdził Sigmund Freud, zadał on bolesną ranę zachodniemu narcyzmowi, przekonując, że człowiek pochodzi od małpy czy też że ma $z$ nią wspólnych przodków66. Oczywiście w przypadku poety w grę wchodzi spór ewolucjonizmu z kreacjonizmem i jego konsekwencje. Niemniej, jak sądzę, największe znaczenie ma dla Norwida kwestia projektu moralnego, jaki buduje on wokół osoby ludzkiej, która jest, jego zdaniem, nieredukowalna do biologii i chemii, odznacza się „wytwornością” (Rzecz o wolności słowa). Oto fragment wykładu Norwida o Juliuszu Słowackim:

Nadzieja, mimo zwycięstwa na Golgocie, odnadzieja się nieraz na powrót, to zwycięstwo albowiem bynajmniej nas od prac i obowiązków nie uwolniło, skąd jest też wiele do walczenia we dnie powszednie nadziei, chociażby dlatego tylko, że z pogaństwem się ciągle spotykamy, bo znów przez dziewiętnaście wieków nagromadzały się i nagromadziły żywioły barbarzyństwa. [...]

Nie trzebaż to nam jeszcze filozofię uczłowieczyć, politykę i ekonomię uchrześcijanić, praktyki religijne odserdecznić - choćby w nas samych? - salonowe formy uprostodusznić, a rubaszność gminną wznieść nad poziom?! [PW-6 418]

Spoiwem tego projektu jest transcendencja, wzorem - Chrystus; świat, paradoksalnie, tkwi w aporii, zbliżył się i oddalił do/od ideału. W ten sposób staje się wyzwaniem dla człowieka religijnego. Jak czytamy w Listach o emigracji:

Przedwieczny wszędzie jest - dlaczegóż nie miałby być w historii? Owóż jest On w historii pr ze z c złowi eka, tak jak w historii każdego człowieka jest przez siebie, przez Boga-człowieka przez Chrystusa. [PW-7 28] ${ }^{67}$

To wypośrodkowanie sprawia, że człowiek przyjmuje istnienie wolnej woli i pozostaje pokorny w pracy przemieniającej czas w wieczność. Usytuowany przeze mnie pomiędzy Novalisem a Baudelaire’em autor Vade-mecum wydaje się bliższy temu pierwszemu, jeśli chodzi o przyjęcie religijnej opowieści o świecie, $z$ kolei temu drugiemu, jeśli chodzi o zwrot ku codzienności, zwykłości, w której człowiek podejmuje swoją naznaczoną wzniosłością religijną misję moralną ${ }^{68}$.

Poezja staje się dla Norwida sposobem kontaktu z sacrum - z pozoru tak jak na gruncie romantycznego ekspresywizmu. Poeta jednak ogranicza możliwości podmiotu w tej mierze, powściąga jego zapędy tytaniczne i narcystyczne ${ }^{69}$; słowo poetyckie musi wyrastać z zewnętrznego Słowa Bożego. Ów kontakt powstaje w relacji, dialogicznie, podczas doświadczania świata, pracy hermeneutyki, która - jak pokazał Wojciech Kudyba - obejmuje także język teologii i język religijny, ożywiając

Zob. M. F o u c a u lt, Nietzsche, Freud, Marks. Przeł. K. M a t u s ze w s k i. „Literatura na Świecie” 1988, nr 6, s. 254 n.

67 Zob. E. Bi eń k ow s k a, Dwie twarze losu. Nietzsche - Norwid. Warszawa 1975, s. 154 n.

68 Zob. van Nieukerken, Perspektywiczność sacrum, s. 209.

69 Piszę o tym w artykule Norwid - zmagania z podmiotowościa. Epifanie poetyckie autora „Vade-mecum” („Pamiętnik Literacki” 2015, z. 4). 
je, łączac $z$ przeżyciami i realizując tkwiący w nich potencjał znaczeniowy ${ }^{70}$. Zobaczmy raz jeszcze pracę owej hermeneutyki - w Podróży po wystawie powszechnej. Tekst ten pokazuje, jak wyobraźnia religijna, chrześcijańska, zapanowuje - usiłuje zapanować - nad religią nowoczesności, którą współtworzyły wystawy powszechne ${ }^{71}$. Poeta niejako odwraca często ukazywany przez siebie proces profanowania świata - np. w wierszach Larwa, Stolica - i nakłada język religijny o proweniencji dantejskiej na przedstawienie tego, co nowoczesne:

Gmach jest elip są, a w niej coraz mniejszych elips aż do środka tyle, ile rodzajów prac i dzieł. Stąd, jako w Czyśćcu, Piekle lub Niebie starego Danta wszystko porządnie i logicznie dokoła się obchodzi i płynnie się wszystko napotyka. [PW-6 203]

Poezja Norwida obejmuje polifonię języków współczesności, usiłuje przepracować je w fragment kształtującej się Wielkiej Całości ${ }^{72}$. Tak wygląda praca moralna między cywilizacją tradycyjna (poczciwa) a atradycyjna (praktyczna). Jak powiada poeta: „jesteśmy DOPIERO ludźmi XIX wieku” (PW-6 418), ciagle doświadczamy więcej „rozłamań” niż „dokończeń” (PW-2 148). Norwid zdaje się spoglądać na nowoczesną cywilizację jak na religie przedchrześcijańskie i związane $z$ nimi kultury, wchłonięte przez chrześcijaństwo i współtworzące jego organiczną całość, do której wniosły one prawdy cząstkowe (Quidam) ${ }^{73}$. W takim duchu wypowiada się w wykładach o Słowackim, stwierdzając, że każda cywilizacja jest względna i że każda ma być środkiem, a nie celem; trzeba $z$ niej twórczo korzystać, by dążyć do prawdy i szerzyć dobro.

Agata Bielik-Robson pisze o postsekularyzmie:

Żadna inna myśl nie zawiera w sobie tyle etycznej czujności wobec groźby urzeczowienia, która zawisła nad nowoczesnościa - sprawna, instrumentalną, a jednocześnie dziwnie „bez-celowa”, coraz silniej upodabniającą się do upiornego rewersu kantowskiej utopii, czyli globalnego „państwa środków”. Nie jest to w żadnym sensie gest anti-moderne, zmierzający ku teologicznej rekonkwiście nowoczesności [...]. Jest to raczej gest reinterpretacji świeckości: gest ukazujący, że u źródeł zachodniego oświecenia, odczarowania i sekularyzacji tkwi pewna decyzja natury religijnej, której zarazem towarzyszy określony zamysł i - właśnie - c el, ponadinstrumentalny, stanowiący wartość autoteliczną ideał radykalnej sprawiedliwości ${ }^{74}$.

To jakby komentarz do zaprezentowanej tu myśli Norwidowskiej, poeta pozornie bywa bliski rekonkwiście, ale podstawowa jego praktyka - jak starałem się

S. Rze p czyńs ki. Słupsk 2003, s. 29 n.

Zob. E. H o b s b a w m, Masowa produkcja tradycji: Europa, lata 1870-1914. W zb.: Tradycja wynaleziona. Red. E. Hobsbawm, T. Ranger. Przeł. M. Godyń, F. Godyń. Kraków 2008, s. 283.

72 Zob. Z. S te fa n ow s k a, Norwidowski Farys. W: Strona romantyków. - A. va n Ni e u ker k e n: „Stygmat” Norwida: $w$ poszukiwaniu znaków Historii Świętej na powierzchni świata. „Słupskie Prace Filologiczne. Seria Filologia Polska” t. 7 (2009); Norwid a pozytywistyczna koncepcja dziejów (Henry Thomas Buckle). W zb.: Norwid wobec historii, s. 385 n.

73 Zob. B. W oł o s zy n, Figura biblijna w twórczości Cypriana Norwida. W zb.: Norwid wobec historii, s. $143 \mathrm{n}$.

74 A. Bi elik-Rob s o n, Powrót mesjańskiej obietnicy, czyli postsekularyzm w sensie ścisłym. W zb.: Deus otiosus, s. 349 n. 
pokazać - polega właśnie na reinterpretacji świeckości, której nowoczesne kształtowanie się twórca obserwuje w XIX wieku. Zarazem poetę zajmuje nie tyle metafizyka czy spekulacja religijna, ile moralność (wiąże się z tym też szczególny nacisk położony na problemy życia jednostkowego), co można potraktować jako osłabienie - jak już wspomniałem, w sensie Vattimowskim - formuły religijności, chrześcijaństwa integralnego, które jednak rezygnuje $z$ integryzmu.

Abstract

MICHAŁ KUZIAK University of Warsaw

ORCID: 0000-0002-7926-5268

\section{POSTSECULAR NORWID? THESES AND TRIALS}

The paper points at the possibilities of Norwid's output reading - the output being rooted in Christianty, both in the dimension of poetics, aesthetics, and that of worldview-in a postsecular perspective. This perspective is devised in the spirit of Charles Taylor's thought that adopts the vision of modernity not only as progressing secularisation, but also as coexistence of secular and religious tendencies. Religion, in this view seen as one of worldview possibilities, is squeezed from the public sphere and made to commence a dialogue with modernity. Norwid's stance suits the horizon of such a dialogue: modernity criticism, reinterpretation of developing secularness, modes of its moral working, and simultaneously opening to the challenges of modernity, as well as drive for reintegration of the order of religion and civilisation. 